\title{
Comparative Study of Causes and Effects of Economic Corruption in Nigeria
}

\author{
Casmir Onyeneke ${ }^{1}$, Edward Victorhez ${ }^{2}$, Nwosu Joyce ${ }^{3}$, Frankline Anyanwu ${ }^{4, *}$ \\ ${ }^{1}$ Department of Mathematics and Statistics, Hezekiah University, Umudi, Nigeria \\ ${ }^{2}$ Department of Computer Science, Hezekiah University, Umudi, Nigeria \\ ${ }^{3}$ Department of English and Literary Studies, Hezekiah University, Umudi, Nigeria \\ ${ }^{4}$ Department of Mathematics and Computer Science, Hezekiah University, Umudi, Nigeria \\ Email address: \\ affrankline@yahoo.com (F. Anyanwu) \\ ${ }^{*}$ Corresponding author
}

\section{To cite this article:}

Casmir Onyeneke, Edward Victorhez, Nwosu Joyce, Frankline Anyanwu. Comparative Study of Causes and Effects of Economic Corruption in Nigeria. American Journal of Theoretical and Applied Business. Vol. 5, No. 2, 2019, pp. 32-39. doi: 10.11648/j.ajtab.20190502.12

Received: August 27, 2019; Accepted: September 6, 2019; Published: September 21, 2019

\begin{abstract}
This work analyzes the terms contributing to economic corruption in the Nigeria. The analyses shows that privatization of public sectors has affected the economy negatively. Some public policies contribute to the growth either negatively or positively to the growth and development of Nigerian economy. In many countries, the way economy is defined is how it is in their country. Some countries, particularly in Africa, have a low decreasing economic growth as a result of corruption and mismanagement. It seems that every year the price of goods and costs of living increase sequentially, example, a litre of fuel was sold at a minimum price of $\$ 60$ in 2012, while in 2018 the minimum price was $¥ 145$ which was not proper. As stated above, 'Economy deals with men in their ordinary business of life, earning and enjoying a living'. From this statement, it was observed that it is not true in Nigeria. Many people have ordinary businesses that earn, but not enjoying any living due to hardship caused by series of corrupt practices. Many people work just to eat two times a day, while some strives to maintain a particular meal type | diet for a weak in order to survive. Some work as civil servants but owed for months by government showing that the business is there but, they are not enjoying any living due to corruption in an economy.
\end{abstract}

Keywords: Economic, Corruption, Privatization, Politics, Health, Employment, Government, Budget, Education

\section{Introduction}

Generations of economists since Adam Smith [1], the acknowledged founder of economic science, have defined 'economics' in various ways, which stating that economy is the activities involving money and exchange transactions among people, allocation of scarce resources to the production and distribution of goods and services, wealth, how man earns his daily bread, and men in their ordinary business of life, earning and enjoying a living. Corruption is the act of changing or of being changed for the worse. It is the act of impairing integrity, virtue, morals principles, loss of integrity, depravity, wickedness, bribery [2]. When impaired integrity, virtue, moral principle, wickedness, bribery is brought to ones | Nations business, earning and living it is said to be economically corrupt. When the virtue of the economy is changed for the worse, it is economic corruption. In Nigeria, one's happiness has turned to hardship, due to the impaired moral principles, impaired integrity and bribery in the economy. Eighty percent of the people cannot boost of balance diet, including adequate three squared meal, due to the economic corruption. Many died and still dying because of insufficient and unbalance diets which has to do with the hardship in the country.

Privatization of public sectors is one of the major causes of economic corruption in Nigeria. This is the transfer of company or asset from government to individual to be controlled and directed by individual [3]. Mass gained something easily from the government, reducing the cost for the people. Privatization of public sectors has caused more harm than good in Africa, things that an individual supposed to gain easily is sold to the first class citizens leaders or 
wealthy ones in the society. The worst part of 'privatization of public sectors' is that, almost all the important companies | structures that helps a Nation to develop is sold to individual to control, thereby proving that individual has power over the citizens and the nation contradicting the 'Rule of law', which says that, Nobody is above the law. Privatization of public sectors makes the individual who gained the sector to decide within him whether to release it services to the nation as well to the mass at his $\mid$ her convenient time, also placing the price of the service so high for the mass, whom the services are meant for at a low cost even at no cost in some extent. Privatization of public sectors causes a lot of harm, it brings about no cooperation among the government, the citizens (mass) and the individual, because government might want it to be in a particular way but due to the individual has been licensed to operate individually, therefore choose to do what will favor him first (not the mass), before the government, then considering the mass at the end point. Privatization brings about maximum devaluation or backsliding in the country, whereby the power and they say is not on one person | government. [4] It means that for things to move appropriately, the individuals that got the license must liaised, agree among them, giving their own terms and condition to the government, then in some cases liaise with the government for a particular work or project to be done. Privatization has created limited access to what the citizens are born to enjoy or access as a citizen.

Privatization has caused a great inflation in the country, increasing the rate of hardship. When an important structure and asset is privatized the licensed individual places his $\mid$ her price for that service and it has been certain that, the individual's price for the service is higher than the price the government would place, because the aid of a government is to help the citizens, while the aim of the licensed individual is to make more earnings and enjoy living. Privatization decreases the nation's income [5]. An asset that is meant for the government which generate income for the nation and for its development, but when privatized all the income will decrease simultaneously, because the government it's self in no longer in charge or control. Privatization has made unbalanced wealth. The area of the licensed individuals seems to develop than unlicensed individual, causing imperfect distribution of wealth in Nation. If the asset is still under the government, it will be easier for the government to distribute and develop all areas to a comfortable level of living. Privatization would bring imperfect employment, whereby the licensed individual whishes on whom he I she wants to employ either by merit, relativity, ties, etc. making group of unknown youths unemployed, if the licensed individual chose to employ people he know, which must surely come to play in terms of employment in a privatized company [6].

EEDC is known as Enugu Electricity Distribution Company. Inconstant electricity has been a source of problem in Nigeria. A country that produces goods worth of billions in a country needs a constant light to enhance good production and when there is no constant electricity, it means that virtue, integrity has been impaired in the economy. As the world moves from one technological level to a sophisticated technology level, some African countries like Nigeria do not have constant electricity due to privatization. Since the twenty first century many citizens of Nigeria were asked severally, 'when last did they experienced constant electricity across the federation', none was able to state a date, proving that since the privatization of electricity in Nigeria, no improvement has been made to ensure a constant electricity like other African countries and some other countries outside Africa. The price of the Electricity bill increases from a small point to another, causing more difficulty [7].

\section{Methodology}

Nigeria is among the countries that have natural resources. Nigeria is blessed with a dam, which generate electricity, yet no constant light. Citizens stay up to a month in their area without electricity, because the licensed individual wants to feed his $\mid$ her pocket first before thinking of how people will benefit from the asset. Few years ago, it was recorded that Ghana celebrated 50years of constant light and the question is that, where is the source of electricity. The same record showed that $t$ heir electricity was generated from Nigeria. The question again is what is wrong? Privatization made the case of economic more complicated, whereby the decision marking now base on the licensed individual. Many companies are not functioning properly because of the privatized electricity. A company that produces 100,000 (one hundred thousand) bags a day when they have spent 400 litres of diesel which cost about 200.00 per litre, will produce more if there is constant light and save cost for the endless expenses made on a cost of producing with diesel. Privatized electricity has made education or learning not been sophisticated [8]. A tertiary institution that teaches with projector or smart screen, computers, public address system fails to work when there is no constant electricity, affecting learning.

\subsection{Dimension of Politics}

In terms of economic corruption, politics has contributed and still contributing to the corruption in the economy. The rate in which politics drives at presently is a major cause of economic corruption. Leadership is meant to be democratic (as in line to Nigeria system of governance 'government of the people by people and for the people, but the ideology is changing to politics here in our country, whereby an individual comes with a motif of doing anything possible to win power | government in order to convey the country's fund to personal | family fund.

It is said that, "good political staff is hard to find; they may neither be ambitious and corrupted by power nor tempted by private sector careers" [9]. Many people joined political party, in order to make family money only instead of moving the nation forward. That is why, many fight each other to gain power and evil on that process claim (kill) souls in order to win or gain power, and become his kindred and 
community. It is rare to see individuals who have joined political parties to discuss the welfare of the nation, rather they fight against each other (opposing the two political parties in question) showing that they are not one in terms of politics. In politics, it seems that a politician from a party within a country is not the same with the other politician, displaying differentiation, discrimination (means that 99.99 percent of the politician s are after the nation's wealth. In many occasion, the commissioners in charge of electing a perfect leader are not playing a perfect role [10]. The organization called INEC (Independent National Electoral Commission) seems to be dependent. It is clear that they are under the influence of the ruling party in many cases. Many of the members enhance partiality; mal-practice etc. in terms of registering citizens voting card it was stated that, the registration is only for adults, from the range of 18 years and above, but today many adolescents have their voting card registered as an adult.

When the vote is cast, many political parties are allowed to share money to the citizens on the day of election, in order to drive they heart away from the right person who will lead the Nation perfectly. Many youths or elderly ones who are facing hardship fall into the trap of accepting the bribe as well as selling their conscience. The question is that, why should political party be allowed to be at the polling unit sharing money to deceive the minds of the citizens facing hardship? In this type of election, it is said to be bribed and integrity has been impaired. Then, what is INEC doing about this, because it has been in scene for years? It is a wrong impression for a political party to elect uneducated and inexperienced leader who will also help in alternating the economy negatively if he $\mid$ she succeeds. Being a developing country, the elected leaders should be educated, experienced, who can represent the citizens anywhere in any condition. Nigerians have failed severely because we have being choosing a wrong leader, who are not really educated nor experienced. A blind man cannot lead the way. When a leader understands what education is all about he or she tends to solve problems likely.

\subsection{Health Dimension}

When one's state is medically balanced, he | she has the tendency of surviving economically. Health issues have being a great obstacle or hindrance in economic development, because when the citizens are not sound psychologically, the rate of production, work is reduced. In Nigeria, governments were able to provide some hospitals, which enable the citizens including the poor and rich to have access to. But, in many places we have insufficient government hospitals, which bring about the increase in urban areas. The percentage of government hospitals that have well equipped medical materials is too poor; conversely, the percentage of hospitals with no good equipment is higher. Many government hospitals functions like only a first aid unit, where you can only take drugs for headache, without having a good equipments that helps in health issues. In Nigeria, private hospitals owned by individual have sophisticated equipments than government owned hospitals [11]. Many government hospitals do not have well qualified operators or doctors. It seems that is mostly those from college operates in place of professional operators, without undergoing series of test, in order to be proved worthy and capable | qualified of being a doctor. In many government hospitals the highest ranked worker you can see would be a 'mid-wife', even though they are experienced, but life needs more advanced techniques or professional to handle cases, because we cannot use what we learnt from apprentice to practice life in terms of death, some needs medically quantified prescription not assumptions. The rates of doctors operating in private hospital (s) are higher than government working doctors. Many private hospitals are well equipped but the bill is too high for the citizens to afford. Many have died because of some high policies unveiled by this private hospitals, since it is well known to them to them that government hospitals are not advanced to save lives, so in that cause, increase the protocols in their system.

If a citizen that tends to survive in the present hardship, wants to see a doctor decides to come or fix an appointment (date) with him (what happens in critical issues?). In many private hospitals, for you to see a doctor, you must deposit a sum of $\$ 10,000$ and above. In some cases, if citizen's issue becomes more critical, doctors in private hospitals exercise supremacy. The citizen has to pay for a bed would be given to him. Thus, for a doctor to finally commerce on his $\mid$ her condition medically, he/she still have to pay for full service as a deposit. At the end the citizen has to pay for the prescribed drugs. If the citizen was able to survive all these stages by the grace of God, he would be mandated to clear all his or her debt (depending on the hospital i.e. they allow patients to go on debt before treatment which is insignificance in many places). By the virtue of clearing the debt, he | she pay for his/her discharging fee. All the listed protocols above are among the procedures in private hospitals since, the private hospital functions effectively than the government hospitals. Many citizens died and still dying because of the cost involved in treating they health issues, since government cannot help her citizens effectively.

\subsection{Employment Criteria}

Nigeria is wonderfully made, blessed and quit unassuming but, citizens are not fifty percent is not favored, showing that the benefit is only meant for those in power and their relatives, while others should find they way out in facing the hardship. Employment has been an economic issue in Nigeria. The industries developed in Nigeria are longer sufficient for her citizens, causing increase in hunger, increase in corruption and complete mass failure. In many areas, if you were able to see a job | work opportunity, for you to be employed, you must meet up to criteria. Some criteria placed on employment are very vital and enhance development, while some are destructive to the nation, bringing division in the nation, discrimination, conflict and economic backsliding. In most places, someone in power or in charge of employing his | her follow citizen considers 
someone from his | her family first, regardless of his or her qualification, achievement and experience. This mentality is drafted from the ideology of one that already rich wanting to make his family, tribe etc. wealthy [12].

Many employees consider people he or she knows, people from his $\mid$ her tribe, clan, kindred, community, state, religion, ethnic group or country than an outsider. In the virtue of employing his | her own people, many illiterates, who did not pass through education are employed degrading the country's economy or production rate. A well educated, qualified citizen either from Yoruba, Hausa, Igbo, etc. will do more, far more better than person from his | her family who have low qualification, knowledge unlike the above stated group. In some places, many people are employed in areas that are not they calling, because " $y$ brother or relative is an employee". Some indulge in bribery before employment in public sectors. The types of favours given are diverse and may include money, gifts, sexual favours, company shares, entertainment, employment and political benefits. The personal gain that is given can be anything from actively giving preferential treatment to having an indiscretion or crime overlooked [13] Someone from computer science department cannot play an effective role in terms of analyzing the nation's economy like an economist would do. Many economic problems are not solved because many people are not specializing on their field or their calling. Some elderly people who are old to retire, but they find it very difficult to retire, occupying space for the young and fresh graduates who knew what they got while in school. The major reason why the old ones forbid retirement is because they are afraid of being a pensioner. Most pensioners in Nigeria are not paid effectively or on time. Some are being owned for months. This gives the old the impression to remain on that seat or position in a company or sector. Many government workers especially teachers are owned for their month's services, after a long suffering service rendered to educate the younger ones in the society. Most times they go home empty handed. When a politician is being paid regularly, who has no much impact to lay on the younger generation, while someone who teaches, inculcate and educate the younger ones who are leaders of tomorrow. What will be the fate of our economy, since the determinants of our economy (teachers that teaches the younger ones) are withheld by not paying the instructors, teachers etc.

\section{Results}

In many places in Nigeria, education is being devalued while politics is valued to the highest point. In some part of Nigeria, many children, youths are not sent to forward their education saying that "education is not the key, key is quick money". By the nature of the hardship many youths, children are sent to hawking, just for them to raise money for food. The time for a child or adult would have used learning in school, he $\mid$ she uses it for striving to survive in the society. Education is being defined as the wealth of a nation (in respect to economics). A country without much educated citizens, the country tends to backslide economically. Example: Some American countries like U.S.A. do not have enough fertile lands for cultivation, becoming a handicapped nation in cultivation (as a whole source of income to the nation. But, with the aid of education they conquered poverty, as well as producing great scientist that was able to manufacture things (technologically based) through education. The computer we all use today manufactured and still be manufactured by people who were educated ("school"). The innovations on how to build industries were all gotten from educational ideology [14]. The most economic fund generating sector in the world is education. Education has produced and still producing great things in the world.

Table 1. Shows the allocation of fund from 2014-2018.

\begin{tabular}{llll}
\hline Year & Federal government annual budget (trn) & Allocation to education (bn) & Allocation to education as \% \\
\hline 2014 & 4.962 & 493.00 & 9.94 \\
2015 & 5.068 & 392.20 & 7.74 \\
2016 & 6.061 & 369.60 & 6.10 \\
2017 & 7.444 & 550.00 & 7.38 \\
2018 & 8.612 & 605.80 & 7.04 \\
Total & 32.147 & 2410.60 & 38.20 \\
\hline
\end{tabular}

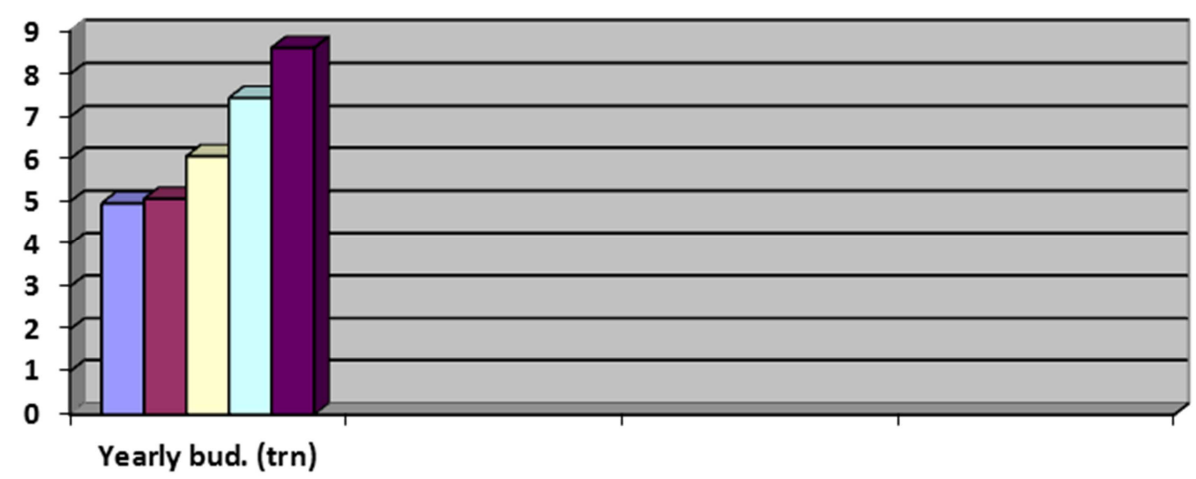




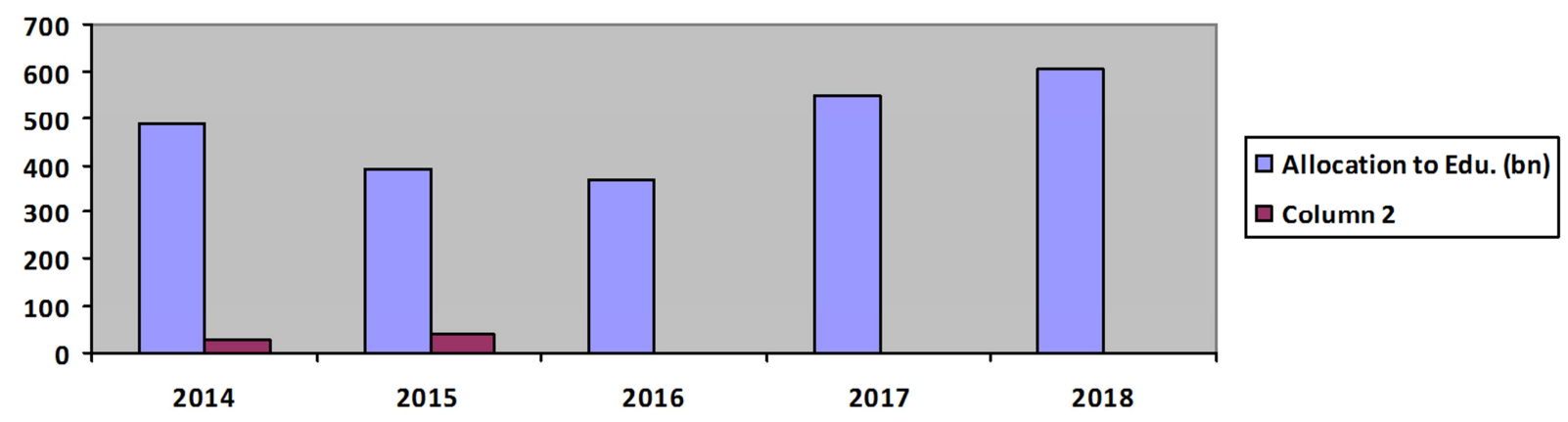

Figure 2. Allocation Made To Education Sector Each Year.

Around 1980s no one knew that we will have handset, laptops. Pelle (footballer) of Brasil never knew that we will have "a goal line technology", during his career in football [15]. Education is being invested in day and day, many development started taking place in technology, which affects the world.

Majority that passed through education were able to effect the world in terms of development. Chinua Achebe affected the world with his literary work. Charlse Barbage affected the world with his own creative invention (computer) which we all enjoy today [16]. Donald Trump and other philanthropists affect the world with good leadership skills, gotten from the knowledge of education. Devaluation of education has caused the Nigeria a lot damages. Many children and adults are being driven home from school because their school fees debt, while some are not in school because of poverty. Many political parties waste money endlessly in the process of campaigning for a particular position, and find it very difficult to launch a scholarship programme. Majority of schools in Nigeria have bad structures, which some places are like shrine. Bad structures in school have made learning nonconductive for the children or the adults. Some schools have no whiteboard, markers, seats (exposed to sitting on the ground) since that's the only alternative. A minor number of schools are operating without books, technical devices (laptops | computers, projectors, and internet access etc.), lacking qualified instructors whereby employing with A | O level are being employed to educate the younger generation which is not supposed, because if the foundation is not solid the whole body must surely collapse.

Government universities go on strikes, which affect the education system, since the instructors are being owed by the government, which may last a year, meaning that lectures size for a whole year, extending the graduation date of student which may require an additional payment whenever the strike is called-off. Some university's lecturers are unfaithful to their job, accepting gifts, illegal packages to pass unserious and serious students. An empty drum (a student) who graduated through sorting will definitely degrade the nation's economy if given opportunity to be in power. In the same note, some lecturers fail the good ones (students) due to he or she decided not to meet up with the destructive desires of the lecturers. Placing the student in dilemma, which some result to carry over (s) accumulating additional year (causing delay). And the delay can cause a set back to the economic growth because, an individual can effect a nation (especially those that have the knowledge).

Some educational boards in Nigeria are not helping matters effectively. An instance is when a student who writes Advanced or Ordinary level having passed successfully, moves to JAMB (registration and examination), if he succeed, he stands to gain admission into any university. If admitted, he is subjected to pay huge amount of money as an acceptance fee. What is the merit in the admission processes if such exorbitant amount is demanded by schools after suffering, reading, and studying to pass through these series of admission tests [17]? Then most number of students on scholarships is under Non-governmental organizations unlike governments. Indiscriminate inflation on goods in Nigeria has been a big problem in economic development. The root of inflation is mostly from the government policies, causing goods unaffordable or affordable but in a little quantity to the citizens. High prices of goods have caused many to reduce their feeding ratio as well affect effective marketing. Indiscriminate inflation causes hardship in the nation, increasing death rate, immigration rate, and rate in which people take unbalanced diet. Banning importation of some essentials goods from developed countries especially eatable goods degrade the choice of citizens and also brings competition, examination, improvement to the locally produced goods.

Exchanging of goods among nations brings co-existence, and tends to solve one another's problem when necessary. A strong relationship is built when exchange takes place among nations. No nation can operate on its own, thereby nation $\mathrm{A}$ needs nation $\mathrm{B}$ as well as nation $\mathrm{C}$ in order to perform effectively. From scientific observations, it was made clear that, children from 21 st century are more intelligent than the previous centuries [18]. The rate in which children of this century assimilate things easily is more astonishing and of a high speed than that of other centuries. Children observe things, retain, and practice. Many families train their children in a nasty way. A lot of corrupt practices, utterances and behaviors, which the parents and the adults depict in the family, the children are placed on a continuous probability of assimilating and retaining the incident or behavior as well as practicing them. Example: An adult or parent that lives with a child, and fond of saying decayed words, definitely the child will grow up with the same behavior. With such behavior, if the child eventually gains a position in future, 
that attitude will be there, transmitting the behavior to his | her dealings, resulting to bad management both economically and psychologically.

Bad family set up has affected the economy, exposing some (offspring) to immorality and illegal acts, since parents bear number of offspring they cannot train. That's why in some areas many students are out of school not as graduates, but as drop outs because of poverty. In families that are low income earners training seven children, it will be hard (very hard) for them to succeed. This situation is liable to illegal acts, like drug trafficking, hawking, prostituting, stealing etc. which brings about corruption in nation, as well as affecting the economy. Many family do not train their children in a God fearing manner or way, even though the family might be wealthy having moderate number of children (which is good), but because of the way the children was trained, they end up becoming cultists in higher schools. And If they are privileged to lead the nation or hold any valuable seats i.e. in a company or civil servant work, their attitude will remain with them in that position. The major cause of economic corruption is the individual mindsets. It involves the aim, vision of an individual which he $\mid$ she will definitely depict. Many individual have set they mind negatively to the economic development, that's why the highest number of leaders in Nigeria (past \& present) were | are after the nation's fund to enrich themselves, leaving the nation and her citizens distressed (subjecting them to poverty).

A nation is the aggregation of people within a territory. The major branch regarded as the future of the people is the "youths". Being a youth without any achievement or impact withdraws the statement, "the future of the nation", from the youth because, you have nothing to offer. Many students in universities do not value education; they portray the attitude that shows they were pushed to study. Some are being forced by parents or guidance to take a particular course which is not their calling. When a student is forced to take a particular course, definitely the years spent is waste, whereby contributing | impacting nothing to the nation. Parents have developed a thought that my son and daughter must be a doctor, barrister etc, and if the he $\mid$ she fails to become such desired aim, he tends to face difficulties. A child that was forced to become a doctor might prescribe wrong drugs to the patients, because it was not his choice. The same is applicable to a child that was forced to become a banker, definitely he $\mid$ she will not be fully active, accountable because, the job is not his field, therefore reducing the rate of getting a credible work, which helps economic development. Majority of students use their academic opportunities as a forum for excessive friendships, fashion parade, recreational period of life. They relax, showing imperfect interest in their field of study, attending lectures twice a week, taking assignments unserious, taking the school library as an enemy, forgetting that, most things (mighty) can be achieved while in school. Students with extra-ordinary achievements tend to help the nation in any sector they find themselves in future, developing the economic sector.

\section{Discussion}

Parents and adults comes into play when the parents of the youths guide them in the right way, it will be difficult for them to deviate in any place they are. When adults and parents mind the way they talk (choice of words), it will help in promoting the integrity of their children, because children adopt things, ideas, observations easily than elderly ones. When a child adopt a good attitude from his | her parent or any adult, with a continuation in education (which supposed to be), the child will be a great instrument to the nation, family and him | herself when (having a good mindset, taking studies serious and a vision of taking his $\mid$ her nation to a greater dimension).

Parents should support their children (child) by not pushing them into a field contrary to his $\mid$ her career $\mid$ calling. A child who is good in sports, crafting, should be invested on, not saying that, "it is local", they should be taught on their area $\mid$ talents. When a child faces his $\mid$ her field, he $\mid$ she will do better than a forced person, improving the state of the economy. It is the belief of political parties that politics is all about embezzling nation's fund. Many parties spend endlessly when campaigning in other to obtain power, and if successful they turn the nation's fund to personal fund, thereby releasing small percentage of the fund to the nation and the citizens [19]. Leadership should be "government of the people, by the people and for the people, not government of the parties by the people and for the parties. Individuals in power should tell another the truth, and those in power table the problems of the citizens to the government as whole. If politicians will be able to tell one another the truth, the nation's fund will not be misused. Independent national electoral commission should be independent as their name implies. They should be free from intimidation from parties or politicians. They should avoid rigging of an election; the winner $f$ an election should be announced irrespective of party. Election should be held ones in the whole state like 2018 America mid-term election, because an electorate can vote in his | her state, still vote for another in the other state. Many may bring in violence due to their state is electing anybody that period.

Registration of PVC (personal voter's card) should be done for adults as stipulated in INEC regulations. It should be made clear, that an outsider is not qualified to vote until he or she meet up to the terms, because he / she may not know the experiences any feelings of the people, before a criminal will be voted into power. The organization, "Economic and financial crime commission" should be allowed to work judiciously and independently without prejudice. Any government, politician or leader found guilty should be charged and fined, as well as facing the necessary punishment. It should be well implemented that, "no one is above the law". The electricity companies in Nigeria should provide constant electricity to the nation, to enable effective production in industries. The cost of electricity (bill) should be reduced, since it country owned source. Privatizing public sectors (companies) should be abolished, because anything 
meant for the nation to enjoy should not be given to any citizen to control. A citizen or team may decide to take laws into his | her hands by a public service at his own time. When education is valued, the economy grows and develops in different sectors. Education should be made compulsory to those eager to attend, because it helps to sharpen citizens' brain and bring out effective ideology from the citizen, most especially the young ones.

Sophisticated materials for learning should be provided to the citizens by the government, because quality impact cannot be made on the youths with insufficient or adequate facilities | tools. The needy ones or some citizens who could not afford the cost of going to school should be sponsored because, the hope (future) of a nation lies on the youths. Youths should be invested on by creating more skill acquisition programs which will enable then get the knowledge on how to raise fund by them, reducing burdens of the nation. A youth that is good in any field should be supported. The growing ones from 15-29, should be receiving a little token as salary from the government, in order to support themselves, reducing the rate of corruption and poverty [20]. This fund will support those that have great intensions, innovations and projects to publicize them, which will promote the image of the country. Citizens should stand firm on who they want as leader, irrespective of money which may be offered to them on the Election Day by political parties. Money offered to citizens on the Election Day to deceive they conscience, can only last for short period, solving short problems, but electing eligible leader will solve the nation's problem for a whole tenure.

Banks should create a medium, where by a citizen can withdraw any amount a day. Pin pointing a particular amount to withdraw a day, will definitely prone citizens to danger, because someone that wants to withdraw and it requires him to withdraw times in three days, when goes to and fro (from work | house to bank) definitely he will trapped by armed robbers. More industries should be constructed to create vacancies to the youths. Eligible youths should be employed according to their qualification, experience, knowledge and problem solving capability, which will help the nation. While the elderly ones who are not strong enough to carry out their duties should give way for the youths, and government should keeping pension to pensioners. Any qualified youth should be given a qualified job, regardless of his | her religion, state or community in order to have a clarified job. Employee should not employ because he $\mid$ she is related to me, neglecting the qualification.

\section{Conclusion}

According to World Bank, policy decisions (elected officials or bureaucrats) can be critical in determining the level of corruption because of the incentives different policymakers face [21]. Economic corruption has caused much harm to citizens and nations. Economic corruption is the source of hunger and poverty. Due to high cost of goods, embezzling of nation's fund and poor management, lack of basic and advanced facilities in schools (including electricity), have caused a lot of damages on the standard way every citizen ought to live. Many citizen lack basic facilities like good water in some areas. Economic corruption causes inflation in the market. It also brings low currency rate, to be compared with world trending currency, and causes devaluation of currency. Many do not have fund to buy high price goods, making them to depend one kind of goods accessible to them, causing eating of unbalanced diet. Economic corruption can cause someone to depend on one meal, and non-conducive shelter, and so on. Economic corruption threatens the life of poor. Corrupt economy places no hope for the citizens and also contributes to nation's conflict. Corrupt economy brings one sided development, leaving most parts, places undeveloped. Corrupt economy favors no one, it is an impaired system.

\section{References}

[1] Locatelli, Giorgio; Mariani, Giacomo; Sainati, Tristano; Greco, Marco (2017). "Corruption in public projects and megaprojects: There is an elephant in the room!" International Journal of Project Management. 35 (3): 252-268. doi: 10.1016/j.ijproman.2016.09.010.

[2] Peter Belohlavek (2017). "Social Corruption and Corruption Inhibitors as a Complex Adaptive System". SSRN. doi: $10.2139 / \mathrm{ssrn} .3066116$.

[3] Abubakar, B. A. (2014). Education and Sustainable National Development in Nigeria: Challenges and way forward. International Letters of Social and Humanistic Sciences Vol. 14.

[4] Hamilton, Alexander (2017). "Can We Measure the Power of the Grabbing Hand? A Comparative Analysis of Different Indicators of Corruption" (PDF). World Bank Policy Research Working Paper Series.

[5] Dauda, R. (2010). Investment in Education and Economic Growth in Nigeria: Empirical Evidence. International Research Journal of Finance and Economics, pp. 158-169.

[6] Mantzaris, E., Tsekeris, C. and Tsekeris, T. (2014). Interrogating Corruption: Lessons from South Africa. International Journal of Social Inquiry, 7 (1): 1-17.

[7] George Psacharopoulos. (1994). Returns to Investment in Education: A Global Update.

[8] Education as a Key to Economic Growth and Development in Nigeria; Vol. 3 | Issue 02 | Pg: 1862-1868.

[9] Dimant, Eugen; Tosato, Guglielmo (2017-01-01). "Causes and Effects of Corruption: What Has Past Decade's Empirical Research Taught Us? a Survey". Journal of Economic Surveys. 32 (2): 335-356. doi: 10.1111/joes.12198. ISSN 1467-6419.

[10] Becker, E. (1962). Investment in Human Capital: A Theoretical Analysis. Journal of Political Economy, Vol. 70, No 5, part 2: Investment in Human Beings, pp. 9-49.

[11] Gylych JELILOV, Ilyas TOPARSLAN. (2015). A Social Assessment of the Goals And Realization of Higher Education In Nigeria. African Journal of Social Sciences (AJSS) Volume 5 (3) 2015, 89-97. 
[12] Jensen, Nathan M.; Malesky, Edmund J. (2017). "Nonstate Actors and Compliance with International Agreements: An Empirical Analysis of the OECD Anti-Bribery Convention". International Organization. 72 (1): 33-69. doi: $10.1017 /$ S0020818317000443. ISSN 0020-8183.

[13] Wang, Peng (2013). "The rise of the Red Mafia in China: a case study of organised crime and corruption in Chongqing". Trends in Organized Crime. 16 (1): 49-73. doi: $10.1007 / \mathrm{s} 12117-012-9179-8$.

[14] Barro, R. (1991). Economic Growth in a Cross Section of Countries. Quarterly Journal of Economics, pp 407-443.

[15] Gbosi, M. (2007). The Nigerian Economy and Current Economic Reforms. Ibadan: Olorunnishola Publishers.

[16] Nuriddeen, E. (1999). The Role and Challenges of Education National Development (The Nigerian Experience). Journal of Educational and Social Research, Vol. 3 No 10.
[17] Romer, P. (1986). Increasing Returns and Long Run Growth. Journal of Political Economy, 91 (5), pp. 723-746.

[18] Suaibu, B. (2006). The Growth Implications of Human Capital Investment in Nigeria, An Empirical.

[19] A. Z. Nowak, Gangadhar Dahal (2016). The contribution of education to economic growth: Evidence from Nepal. International Journal of Economic Sciences, Vol. V (2), pp. 22-41. 10.20472/ES.2016.5.2.002.

[20] Olken, Benjamin A; Pande, Rohini (2012). "Corruption in Developing Countries". Annual Review of Economics. 4: 479-509. doi: 10.1146/annurev-economics-080511-110917. hdl: $1721.1 / 73081$.

[21] Hamilton, Alexander (2013). "Small is beautiful, at least in high-income democracies: the distribution of policy-making responsibility, electoral accountability, and incentives for rent extraction" (PDF). World Bank. 